\title{
NOTES ON MELIORNIS NOVAEHOLLANDIAE
} NOVAEHOLLANDIAE AND M. N. DIEMENENSIS.

\author{
By GREGORY M. MATHEWS.
}

T $\mathrm{N}$ a collection of skins from New Sonth Wales sent me by my friend Dr. J. 1 Barton Cleland I notice a change in the colour of the iris from the "café-an-lait" colour of the immature male, first into greyish white, then to a white very faintly tinged with grey (in a male with small testes), and finally to enamel-white in a fully adult male with enlarged testes.

All the fully adults have quite white iris.

It is also interesting to note that a specimen of Zosterops caerulescens in full breeding plumage was obtained in June, i.e. in the Australian winter.

\section{Description of the Eggs of}

\section{Meliornis novaehollandiae diemenensis Mathews.}

Clutch three. Shape roundish, surface slightly glossy. Gronnd-colour buff, with a tinge of pink; at the larger end a band of reddish spots with fewer greybrown ones. Axis 195 , diameter $15.5 \mathrm{~mm}$.

\section{NOTES ON ARCTIANAE AND DESCRIPTIONS OF A FEW NEW SPECIES.}

By the Hon. WALter ROThSChild, Ph.D.

\section{Automolis schistaceus sp. nov.}

ठ. This is nearest to A. ardesiaca Rothsch. Pectus slate-grey with steel-green gloss; palpi black with steel-green gloss; head and antennae black; tegulae and shoulder-patches buffy yellow; rest of patagia and thorax slate-grey; first two segments of abdomen dark buffy yellow, rest of abdomen blackish slate, a paler grey patch on terminal and subterminal segments.—-Forewing slate-grey, a buffy yellow transverse band reaches from the costa to inner margin across centre of cell expanding towards inner margin. Hindwing, basal two-fifths buffy yellow, apical three-fifths slate-grey.

Length of forewing : $20-23 \mathrm{~mm}$.

Hab. San Esteban, Venezuela, June 1909 (S. M. Klages).

$2 \delta \delta$.

\section{Automolis tanialoides sp. nov.}

ठ. Very close to taniala Schans and latania Druce. Legs orange-yellow, forecoxae orange-yellow, middle and hindcoxae earth-brown; palpi orange-yellow ; head black, metallic blue spots on frons and vertex, spots at base of antennae and band across frons orange-yellow; tegulae orange with broad sooty black lateral 
margins; patagia and thorax orange, latter with broad central sooty stripe; abdomen black, dorsal and subdorsal metallic blue patches on last four segments, large latero-subdorsal patches of orange on second segment and smaller ones on third; antennae black._— Forewing orange, a wide brown-black marginal band expanding broadly at termen and narrowing sharply from centre to base of inner margin. Hindwing, costal half orange, lower half brown-black.

Length of forewing: $20.5 \mathrm{~mm}$.

Hab. San Esteban, Venezuela, June 1909 (S. M. Klages).

5 ठठ ठे.

With this new species came $25 \delta \delta$ of $A$. latania Drace.

\section{Automolis pseudoguapisa sp. nov.}

. Closely allied to guapisa Schans. Pectus and coxae metallic blue; palpi brown-black; legs, tarsi orange, tibiae brown-black; head black, blue spots on frons and vertex, minute orange spots at base of antennae; antennae black ; tegulae and patagia orange with broad brown-black borders; thorax brown-black ; abdomen black with dorsal and lateral blue patches, underside of abdomen black with subdorsal orange patches on first three segments.-_ Forewing dark purplebrown, nervures pale earth-brown, an oblique orange streak from base of vein 1 to base of vein 2 and a very indistinct orange-brown patch between veins 5 and 6 . Hindwing deep purple-brown, an orange rather narrow band runs from base of wing through cell two-thirds across the wing.

б. Pectus deep blue; forelegs, tarsi and tibiae orange, coxae black-brown with orange patch on inner side at base; palpi and antennae black-brown; head black, a blue patch on frons and vertex, orange spot at base of antennae larger than in $q$, tegulae and patagia more orange, i.e. with narrower dark borders; abdomen with subdorsal yellow patches, which in two specimens are almost obsolete.-Forewing dark purple-brown with yellowish nervures, an orange oblique band crosses the wing from just before base of vein 1 to middle of vein 6 . Hindwing, costal half dark yellow with central dark stigma, tornal half dark brown.

Length of forewing: \& $23.5 \mathrm{~mm}$. ; $\delta 17-22 \mathrm{~mm}$.

Hab. San Esteban, Veneznela, June 1909 (S. M. Klages).

$10 \delta \delta, 2 q q$ ( $q$ type).

\section{Neritos syntomoides sp. nov.}

ठ. This remarkable little insect is almost an exact mimic of the Syntomid Loxophlebia hemileuca Butl. Pectus, coxae and tibiae pale yellow; tarsi pale brown; palpi brown; head black; shoulder-patches orange, rest of thorax black; a bdomen deep orange, last segment black; antennae brown tipped with white. Forewing black, a large ovate orange patch below cell reaching from median nervure to inner margin, a white wedge-shaped patch in cell, and a large buff patch beyond cell reaching from vein 3 to subcostal nervure; termen narrowly white. Hindwing, basal two-thirds orange, marginal third black.

Length of forewing : $12.5 \mathrm{~mm}$.

Hab. Aroewarwa Creek, Maroewym Valley, Surinam, June 1905 (S. M. Klages). 1 d.

In my former articles on Arctianae I described two insects as Halisidota walkeri and H. walkeri major. H. walkeri is true catenulata Hübn. The origin of 
this error was that the insect which has stood in most collections, my own inclnded, as catenulata Hübn. is texta Herr. Schäff., which latter Sir George Hampson pnt as a synonyn of catenulata Hübn. but which is a perfectly distinct species. The $\delta$ of my walkeri major is a good species and must stand as Halisidota major Rothsch., but the $q$ I associated with it is a $q$ of annulosa Walk.

I unfortunately identified a wrong insect as Halisidota androlepia Dogn., and so redescribed the true androlepia as sobrenoides. I here describe what I had under the name of androlepia as :

\section{Halisidota dognini sp. nov.}

§. Legs orange-buff ringed with brown; pectus buff; palpi orange-buff, extreme tip of third segment brown; head orange-buff; antennae pale brown; thorax orange-bnff with black dots on tegulae and patagia; abdomen buff washed with a darker shade._- Forewing deep orange-bnff, nervures orange, the whole wing sown with dark brown dots and spots, a quadrate dark brown patch in cell and a larger irregular one on discocellulars. Hindwing semihyaline buff.

ๆ. Similar but larger.

Length of forewing: $\delta 25 \mathrm{~mm}$; $+28 \mathrm{~mm}$.

Hab. Santo Domingo, Carabaya, Pern, $6000 \mathrm{ft}$., wet season, January 1902 (G. R. Ockenden).

A small series of $\delta \delta$ and $q q$.

My Diacrisia pseudomaenas is the true venosa Moore; the insect called renosa in the British Museum Catalogue is D. neurica Hmpsn. nom. nov.

Automolis hyalina Rothsch. belongs to the genus Antaxia.

Automolis collateralis Rothsch. nec Hmpsn. = Automolis maura Schaus.

Ischnocampa pellucida Rothsch. = Microdota lenistriata Dogn.

Hyponerita borealis Rothsch. = Neritos tipolis Druce.

Mallocephala venosa Rothsch. $=\delta$ of Maenas surgens Walk.

Haemanota cubana Rothsch. = Neritos sanguidorsia Schaus. 


\section{$2 \mathrm{BHL}$ Biodiversity Heritage Library}

Rothschild, Lionel Walter Rothschild. 1910. "Notes on Arctianae and descriptions of a few new species." Novitates zoologicae : a journal of zoology in connection with the Tring Museum 17, 504-506.

https://doi.org/10.5962/bhl.part.13696.

View This Item Online: $\underline{\text { https://www.biodiversitylibrary.org/item/22248 }}$

DOI: https://doi.org/10.5962/bhl.part.13696

Permalink: https://www.biodiversitylibrary.org/partpdf/13696

\section{Holding Institution}

Natural History Museum Library, London

\section{Sponsored by}

Natural History Museum Library, London

\section{Copyright \& Reuse}

Copyright Status: Public domain. The BHL considers that this work is no longer under copyright protection.

This document was created from content at the Biodiversity Heritage Library, the world's largest open access digital library for biodiversity literature and archives. Visit BHL at https://www.biodiversitylibrary.org. 